Gi respons på artikler gjennom artiklenes kommentarfelt på tidsskriftet.no.

Innleggene publiseres fortløpende på Tidsskriftets nettside og et utvalg

av innleggene publiseres også i papirutgaven i spalten «Brev til redaktøren».

Redaksjonen forbeholder seg retten til å foreta redaksjonelle endringer.

Forfattere av vitenskapelige artikler har tilsvarsrett, jf. Vancouver-gruppens regler

\section{Re: Praksiskonsulentordningen ved et veiskille}

Odd Kvamme har et tankevekkende innlegg om Praksiskonsulentordningen (PKO) i Tidsskriftet nr. 16/2015 (1). Tankevekkende fordi jeg som sykehuslege i de 20 årene ordningen har eksistert, aldri har sett en praksiskonsulent medvirke i sykehushverdagen. En uformell rundspørring i lunsjen ga samme resultat. På mitt forrige sykehus, for drøyt ti år siden, så vi skiltet på kontordøra, og pasientene som ventet i gangen utenfor. Allmennpraksisen gikk tydeligvis sin gang. Vi sykehusklinikere verken så eller hørte praksiskonsulenten.

Ifølge Kvamme er virkefeltene bl.a. «logistikk, kliniske retningslinjer, forbedring av henvisninger og epikriser, IT-kommunikasjon». Da må jeg spørre: Hvilken logistikk og hvilke kliniske retningslinjer i sykehus er utarbeidet med hjelp av praksiskonsulent? På hvilken måte har praksiskonsulentene påvirket travle allmennlegers henvisningspraksis? Sykehuslegenes epikriser har også varierende standard. Men når var en praksiskonsulent involvert i å forbedre epikrisene? Jeg har skrevet noen tusen epikriser, kontrasignert like mange, og aldri, aldri fått råd eller innspill fra en praksiskonsulent. IT-kommunikasjon er ifølge Kvamme også blant praksiskonsulentens arbeidsoppgaver. Vi bruker fax og B-post. E-post er forbudt. I «journalsystemet» DIPS, innført i Oslo universitetssykehus i fjor, går epikrise og poliklinikknotat ikke automatisk til fastlegen. Det kommer ikke en gang opp som en lett valgbar opsjon. Det er vanskelig å skrive et korrekt adressert og «knyttet» brev som respons på en henvisning. Jeg skal ikke gi praksiskonsulentene skylda for denne elendigheten. Men hva har de faktisk bidratt med i våre systemer for kommunikasjon med førstelinjetjenesten?

Ved å søke på «PKO» på Oslo universitetssykehus sine nettsider (2), er inntrykket det samme: Gode intensjoner og store ord. Siste produkt fra praksiskonsulentordningen i OUS var, etter det jeg ser på nettet, et infobrev til fastlegene, datert september 2014.

PKO er full av intensjoner som alle kan støtte, men er det et paradoks at vi som jobber klinisk i en hektisk sykehusavdeling, aldri har sett en praksiskonsulent? Er PKO en av de utallige «ordningene» som er innført med gode intensjoner, men som sykehusene like gjerne kunne klart seg uten? Nå skal det meste telles, evalueres, kvalitetsvurderes, kostnadsberegnes og prioriteres. Kan noen opplyse hvor mange årsverk som har gått med, hva det koster og hva PKO faktisk, dokumenterbart har bidratt med? Tall. Konkrete resultater, i norsk virkelighet.

Kanskje det er på tide, etter 20 år, å se om PKO gir målbar, relevant kvalitetsforbedring? Kanskje kunne pengene heller brukes til noen ekstra stillinger for leger i spesialisering, for å gi bedre tid i pasientarbeidet? Kanskje kunne allmennlegeårsverkene som går med, heller vært satt inn i sykehjem? Jeg spør: Kanskje PKO ikke er ved et veiskille, men ved veis ende?

\section{Torkel Steen}

tostenn@online.no

Torkel Steen (f. 1963) er overlege og spesialist i indremedisin og hjertesykdommer ved Oslo universitetssykehus, Ullevål.

Ingen oppgitte interessekonflikter.

\section{Litteratur}

1. Kvamme 0. Praksiskonsulentordningen ved et veiskille. Tidsskr Nor Legeforen 2015; 135: 1440
2. Oslo universitetssykehus. Praksiskonsulentordningen (PKO). http://www.oslo-universitetssykehus.no/fag/samhandling/ praksiskonsulentordningen-pko (22.9.2015).

\section{Re: Legehelter - og antihelter}

Tidsskriftet nr. 15/2015 ga grunn til refleksjon omkring evidensbasert medisin og gyldige kilder til kunnskap for norske leger. For det første ble en ny artikkelsjanger sjøsatt: Klinisk oversikt. Skjønt ny? Heller en renessanse for nyttige artikler som er kommet i vanry det siste tiåret: Tilgjengelig evidens filtrert gjennom erfarne klinikeres gode skjønn, blottet for unnskyldninger om at nettopp skjønnet og den erfaringsbaserte kunnskapen også har fått spille med. Artikkelen om klasehodepine (1) ble en flott debut: Presis, kunnskapsbasert, poengtert, og samtidig mer blodfylt, morsommere å lese, nyttigere enn dagens gjengse oversiktsartikler som ikke tør mene noe der det ikke foreligger en metaanalyse. Honnør til forfatterne som skrev og til redaktøren som så behovet for en ny sjanger!

For det andre to kasuistikker i serien Noe å lære av $(2,3)$. Kasuistikkene illustrerer at medisinen går fremover ikke bare gjennom Cochranebevegelsens arbeid, men også som en frukt av akkumulert klinisk erfaring, bedre basalmedisinsk innsikt og ny forståelse av sykdomsmekanismer. Heldigvis finnes fortsatt klinikere som tør å gjennomføre et selvstendig patofysiologisk resonnement og ikke bare lene seg på retningslinjene, og som publiserer erfaringene. Slik bidrar de til at vi alle kan lære noe, og dessuten til at erfaringer etter hvert kan systematiseres og - i noen tilfeller - sågar gjøres til gjenstand for randomiserte undersøkelser.

For det tredje - og ikke mindre tankevekkende - den ledsagende lederartikkelen fra Kunnskapssenteret (4). Siv Cathrine Høymork konkluderer riktig nok (under tvil?) med at det kan være riktig å gjøre noe som ikke står i retningslinjene for å redde pasientens liv, men lederartikkelen oppfatter jeg mest som en raljering med «legeromanheltene» som ikke viser den tilbørlige lydighet mot Kunnskapssenteret og deres selvbestaltede sannhetsmonopol. Ja, selvsagt er skjevrapportering et problem, selvsagt må klinikere sette seg inn i tilgjengelig evidens, selvsagt skal erfaringer og patofysiologisk resonnement brynes mot de randomiserte studienes strenge logikk. Men det virkelig bekymringsfulle er at en fagdirektør i en etat med over 200 ansatte skriver at behandlingen fortrinnsvis skal være nedfelt i faglige retningslinjer (andre avsnitt). Nei, så fattig er moderne medisin heldigvis ikke, noe Tidsskriftet med all mulig tydelighet illustrerer (1-3). Men vulgærcochranismen (5) lever tydeligvis i beste velgående i Kunnskapssenteret.

\section{Torgeir Bruun Wyller}

t.b.wyller@medisin.uio.no

Torgeir Bruun Wyller (f. 1960) er professor og overlege ved Geriatrisk avdeling, Oslo universitetssykehus. Ingen oppgitte interessekonflikter.

\section{Litteratur}

1. Alstadhaug KB Ofte HK. Klasehodepine. Tidsskr Nor Legeforen 2015: 135 $1361-4$

2. Brede JR. En kvinne i 70-årene med dekompensert hjertesvikt under operasjon. Tidsskr Nor Legeforen 2015; 135: 1366-8

3. Bjørk MH, Gjerde IO, Tzoulis C et al. En mann i 50-årene med høyt ferritinnivå og økende kognitiv svikt. Tidsskr Nor Legeforen 2015; 135: 1369-72.

4. Høymork SC. Legehelter - og antihelter. Tidsskr Nor Legeforen 2015; 135: 1336. 5. Wyller VB, Wyller TB. Evidensbasert medisin - et kritisk innspill. Nytt Norsk Tidsskrift 2013; 1: 61-9. 